\title{
Effect of Advanced Fibrosis Presence on Adherence to Hepatocellular Carcinoma Surveillance in Chronic Hepatitis C Patients with Sustained Virologic Response
}

\author{
Kalıcı Viral Yanıtı Elde Edilen Kronik Hepatit C Hastalarında Ileri Fibrozis Varlığının \\ Hepatoselüler Karsinom Tarama Uyumuna Etkisi
}

๑ Göktuğ Şirin, @ Sadettin Hülagü

Kocaeli University Faculty of Medicine, Department of Gastroenterology, Kocaeli, Turkey

\begin{abstract}
Objectives: Although hepatocellular carcinoma $(\mathrm{HCC})$ screening is accepted as standard care in patients with chronic hepatitis $\mathrm{C}(\mathrm{CHC})$ diagnosis, sustained viral response (SVR) has been obtained by treatment and it is not certain what the condition is in the group of patients with advanced fibrosis who are at increased risk for developing HCC before treatment. In this cohort of patients, the practice of $\mathrm{HCC}$ was intended to be evaluated in real life conditions. Materials and Methods: Between 2007-2019, the information cards of the patients diagnosed with $\mathrm{CHC}$ were retrospectively examined. Patients with advanced fibrosis, prior the treatment, who had obtained SVR were enrolled in the study. HCC screening was defined as alpha-fetoprotein testing and liver imaging combined. HCC surveillance every 6 months or more was defined as compliance with screening guidelines.

Results: The number of patients in the study was $83(n=32$, cirrhosis). During the follow-up period, the median was 35 (13-124) months, $24(6.1 \%)$ patients were diagnosed with HCC. 48.2\% $(n=40)$ of the patients observed screening guidelines, while $22.9 \%$ $(n=19)$ did not follow the guidelines; $28.9 \%(n=24)$ did not have screening.

Conclusion: $\mathrm{HCC}$ screening in $\mathrm{CHC}$ patients with advanced fibrosis is not carried out in accordance with the guidelines.

Keywords: Hepatocellular carcinoma, advanced fibrosis, hepatocellular cancer surveillance, chronic hepatitis C
\end{abstract}

ÖZ

Amaç: Kronik hepatit C (KHC) tanılı hastalarda, hepatoselüler karsinom (HCC) taraması standart bakım olarak kabul edilmesine rağmen, tedavi ile kalıcı viral yanıt (KVY) elde edilmiş olup, tedavi öncesi HCC gelişimi açısından artmış risk taşıyan ileri fibrozisli hasta grubunda durumun ne olduğu konusu kesinlik kazanmamıştır. $\mathrm{Bu}$ hasta kohortunda, HCC taraması pratiğinin, gerçek yaşam koşullarında değerlendirilmesi amaçlandı.

Gereç ve Yöntemler: 2007-2019 tarihleri arasında, tanı almış KHC tanılı hastaların bilgi kartları retrospektif olarak incelendi. Tedavi öncesinde ileri fibrozisi olan ve KVY elde edilen hastalar çalışmaya alındı. HCC taraması tanımı, alfa-fetoprotein tetkiki ve karaciğer görüntülemesinin birlikte yapılması olarak yapıldı. HCC taramasının 6 ayda bir veya daha sık yapılması tarama kurallarına uyulması olarak tanımlandı.

Bulgular: Çalışmaya dahil edilen hasta sayısı 83 idi $(n=32$, siroz). Ortanca $35(13-124)$ ay olan takip süresi boyunca, $24(\% 6,1)$ hasta HCC tanısı aldı. Hastaların \%48,2'sinde $(n=40)$ tarama kurallarına uyulduğu, \%22,9'unda $(n=19)$ kurallara uyulmadığı ve hastaların $\% 28,9^{\prime}$ unda $(n=24)$ ise tarama yapılmadığı görüldü.

Sonuç: Ileri fibrozisi olan KHC hastalarında HCC taraması, kılavuz önerilerine uygun yapılmamaktadır.

Anahtar Kelimeler: Hepatoselüler karsinoma, ileri fibrosis, hepatoselüler kanser taraması, kronik hepatit C

Şirin G, Hülagü S. Effect of Advanced Fibrosis Presence on Adherence to Hepatocellular Carcinoma Surveillance in Chronic Hepatitis C Patients with Sustained Virologic Response. Viral Hepat J. 2020;26:32-38. 


\section{Introduction}

Hepatitis C virus (HCV), a single-stranded RNA virus in the Flaviviridae family, is one of the major causes of chronic liver disease, cirrhosis, and hepatocellular carcinoma (1). Identified first in 1989, the global prevalence of this virus is estimated at approximately $2.5 \%$ (2). In a study performed on 5460 people in 2015 in Turkey that is considered as one of the low endemic regions for HCV by the World Health Organization, seroprevalence of $\mathrm{HCV}$ was $1 \%$, and the genotype $1 \mathrm{~b}$ was reported as the most frequently detected subtype (3).

Of the patients infected with $\mathrm{HCV}, 15-40 \%$ recover and the remainders develop chronic hepatitis $\mathrm{C}(\mathrm{CHC})$ infection (4). $\mathrm{CHC}$ progresses to cirrhosis in $20-30 \%$ of untreated $\mathrm{CHC}$ patients, and $1-4 \%$ of the cirrhotic patients develop hepatocellular carcinoma per year (5). Liver cancer is the second most common cause of cancer-related deaths across the world and the $6^{\text {th }}$ most common cancer (6).

$\mathrm{CHC}$ infection rarely leads to the development of hepatocellular carcinoma ( $\mathrm{HCC}$ ) without advanced fibrosis or cirrhosis and it differs from $\mathrm{CHB}$ infection in this respect $(4,7)$. The vast majority of the cases with $\mathrm{HCC}$, which is generally observed in $\mathrm{CHC}$ patients with the developed cirrhosis and is the most common cause of the liver-related deaths in this patient group, is unfortunately detected at the advanced stage, therefore these patients cannot benefit from the curative treatment options that can be used at the early stage (2). Indeed, a study performed by Stravitz et al. (8) suggests that the quality of HCC surveillance may have a highly important impact on diagnosis, treatment and survival.

The patients who achieved a sustained virologic response (SVR) with the use of conventional combination of pegylatedinterferon+ribavirin ( $\mathrm{PI}+\mathrm{R}$ ) or the direct-acting agents (DAA), which have been introduced in the recent years, are considered to be cured since their late relapse rates are highly low (9). However, although the risk of the HCV-related fatal complications is reduced after the achievement of a SVR, it is not completely ruled out. Even though non-cirrhotic patients with negative HCV-RNA results at Week 48 can be excluded from the follow-up, it is recommended, due to the ongoing HCC risk, to continue to follow the patients with advanced fibrosis up even after the achievement of a SVR (10).

Current HCC surveillance guidelines emphasize that it is appropriate to perform a surveillance using serum alpha-fetoprotein (AFP) test and liver ultrasonography (USG) together (because of that the individual uses of the tests have their own specific problems, and the sensitivity and specificity of AFP is low) every 6 months in patients at risk (10).

Although HCC surveillance is accepted as the standard care and the effect of the surveillance performed in accordance with the recommended guidelines on the patient survival has been demonstrated, the extent, to which the surveillance guidelines and recommendations are adhered in real life, should be investigated. Even though there is a limited number of studies related to the surveillance adherence of this patient group in the literature, a sustained virologic response has been achieved with the treatment. However, the condition in the patient group at an increased pretreatment risk for the development of HCC remains unclear.
In this study, we aimed to evaluate the practice of HCC surveillance in real-life conditions in the cohort of the $\mathrm{CHC}$ patients with advanced fibrosis who achieved a SVR with treatment.

\section{Materials and Methods}

\section{Patient Population}

In this retrospective cohort study, the information cards of the patients diagnosed with $\mathrm{CHC}$, for which antiviral treatment (including direct-acting antivirals) was initiated by our Gastroenterology Department of our University between May 2007 and May 2019, were retrospectively reviewed. Patients that achieved a SVR with treatment and were followed up for more than 12 months after this response were evaluated taking their demographic and clinical information into consideration. Patients who had advanced fibrosis before the treatment were included in the study. HCV-RNA results, liver function tests, liver synthesis capacity tests, hemogram, AFP and liver biopsy results and hepatobiliary system imaging results [Abdominal USG, magnetic resonance imaging (MRI) and computed tomography $(\mathrm{CT})$ ] of the patients older than 18 years in this group along with the treatments they received (including the conventional $\mathrm{PI}+\mathrm{R}$ and $\mathrm{DAA}$ ) were reviewed. Patients who are under 18 years, did not achieve a SVR with treatment, were diagnosed with HCC before the treatment or follow-up or received curative treatment accordingly, were diagnosed with HCC within the first 6 months of the follow-up, had a history of liver transplant, were co-infected with HBV and/or HIV, and have missing data were excluded from the study.

\section{Definitions Used in the Study}

Based on the liver biopsy performed before the treatment, the patients who were reported at stage 3 or 4 (F3 or F4, respectively) were accepted as patients with non-cirrhotic advanced fibrosis while the patients who were reported at stage 5 or 6 (F5 or F6, respectively) were accepted as patients with cirrhosis (cirrhotic advanced fibrosis) using the Ishak scale (11).

Cirrhosis diagnosis was made based on the detection of cirrhosis in liver biopsy (F5 or F6) and for the patients with unsuitable conditions for biopsy, the detection of radiological and biochemical findings consistent with cirrhosis (cirrhosis without biopsy). HCC surveillance was defined as the combination of AFP examination and liver imaging (abdominal USG and/or abdominal CT or MRI).

HCC surveillance every 6 months or more frequent was defined as "adherence to the surveillance", the surveillance every 7-12 months was defined as "suboptimal adherence to the surveillance", the surveillance every 13-24 months was defined as "non-adherence to the surveillance" and other situations were defined as "no surveillance".

\section{Study Objectives}

It was investigated how often HCC surveillance was performed, whether it was in accordance with the current guidelines, or it differed among patients with advanced fibrosis with or without cirrhosis or among different treatment groups. Factors affecting the surveillance were evaluated. The ethics committee approval for the study was obtained from the Local Ethics Committee of Kocaeli University (approval number: 327, date: 2019). Informed consent was obtained from all individual participants included in the study. 


\section{Statistical Analysis}

All statistical analyses were performed using IBM SPSS for Windows version 20.0 (SPSS, Chicago, IL, USA). Descriptive statistics were reported as proportions (\%) for categorical variables and mean \pm standard deviation or median interquartile range for continuous variables. Comparative analysis between groups was performed using the ki-kare test for categorical variables. For continuous variables, the Student's t-test was used to evaluate normally distributed continuous variables, and the Wilcoxon ranksum test was used to evaluate continuous variables that were not normally distributed. Statistical significance was defined as a twotailed $p$ value $<0.05$.

\section{Results}

In the examination of the information cards of the patients who were diagnosed with $\mathrm{CHC}$ and followed by the Department

\begin{tabular}{|l|l|}
\hline $\begin{array}{l}\text { Table 1. Clinical and demographic features of patients with advanced } \\
\text { fibrosis before treatment }\end{array}$ \\
\hline $\begin{array}{l}\text { Number of patients with advanced fibrosis } \\
\text { (n) }\end{array}$ & 83 \\
\hline Number of patients with liver biopsy (n) & 73 \\
\hline Age & $55.8 \pm 21.4$ \\
\hline Sex (male/female) (n) & $57 / 26$ \\
\hline Genotype n (\%) & \multicolumn{2}{|l|}{} \\
\hline 1 (A/B) & $74(6 / 68)(89.1)$ \\
\hline 2 & $3(3.6)$ \\
\hline 3 & $4(4.8)$ \\
\hline 4 & $2(2.4)$ \\
\hline Cirrhosis (with liver biopsy) (n) & 22 \\
\hline Cirrhosis (without liver biopsy) (n) & $10^{*}$ \\
\hline Histology (n) Ishak et al. (11) & 73 \\
\hline F3/F4/F5/F6 & $25 / 26 / 16 / 6$ \\
\hline Patients with advanced fibrosis/cirrhosis (n) & $51 / 32$ \\
\hline Follow-up duration (months); mean (range) & $35(13-124)$ \\
\hline Number of patients with SVR (n) & 83 \\
\hline Treatment regimes (Peg-IF+RBV/DAAs) & $(46 / 37)$ \\
\hline $\begin{array}{l}\text { SVR: Sustained viral response, Peg-IF: Pegile interferon; RBV: Ribavirin; DAAs: } \\
\text { Direct acting antivirals }\end{array}$ \\
\hline
\end{tabular}

of Gastroenterology of our university during the abovementioned period, there were 393 patients that achieved a SVR with an antiviral treatment, 95 of them with direct-acting antiviral treatment. Of the patients, $57 \%(n=224)$ were male and the mean age was $53.7 \pm 17.2$. Of these patients, $94.9 \%(n=373)$ had genotype 1 , $1.5 \%(n=6)$ had genotype 2 and $3.6 \%(n=14)$ had other genotypes.

The rate of patients with advanced fibrosis, including cirrhosis, was $21.1 \%(n=83)$ (according to the Ishak scale, cirrhosis $38.6 \%$ $n=32 ; F 5 n=16 ; F 6 n=6$; cirrhosis without biopsy $n=10$ ). The mean age was 55.8 \pm 21.4 in this patient group (57 men, 26 women; $89.1 \%(n=74)$ genotype 1). Demographic and clinical characteristics of the study patients are presented in Table 1.

Eleven (34.4\%) of the patients with cirrhosis were decompensated (12 of the patients (37.5\%) had a history of decompensation). MELD score was $11 \pm 2.6$ in this patient group. Based on the evaluation of all cirrhotic patients, the number and proportion of patients in the Child A, B, C group according to the Child-Pugh-Turcotte classification were 21 (65.6\%), 9 (28.1\%) and $2(6.3 \%)$, respectively (Table 2$)$.

During the median follow-up period of 35 (13-124) months, 24 (6.1\%) patients were diagnosed with HCC.

\section{Adherence to Hepatocellular Carcinoma Surveillance Guidelines}

The surveillance guidelines were adhered in $48.2 \% \quad(n=40)$ of the patients while they were not adhered in $22.9 \% \quad(n=19)$ (screening was performed in 11 patients $(13.3 \%$ ) every 7-12 months and in 8 patients (9.6\%) every 13-24 months), and no surveillance has been performed in $28.9 \%(n=24)$ of the patients. HCC surveillance rates are presented in Table 3.

\begin{tabular}{|l|l|}
\hline \multicolumn{2}{|l|}{ Table 2. Features of patients with cirrhosis before treatment } \\
\hline Number of patients with cirrhosis $(\mathrm{n})$ & 32 \\
\hline Biopsy (+)/(-) & $22 / 10$ \\
\hline Child-pugh score (n) (\%) & $21(51.0)$ \\
\hline A & $9(35.3)$ \\
\hline B & $2(13.7)$ \\
\hline C & $11 \pm 2.6$ \\
\hline MELD score & 11 \\
\hline Number of patients with decompansated (n) & 12 \\
\hline $\begin{array}{l}\text { Number of patients with history of } \\
\text { decompensation (n) }\end{array}$ & \\
\hline MELD: Model for end stage liver disease \\
\hline
\end{tabular}

\begin{tabular}{|c|c|c|c|c|}
\hline $\begin{array}{l}\text { Advanced fibrosis, } \\
\text { (with and without Cirrhosis) }(n=83) \\
\text { HCC Surveillance adherence; } n(\%)\end{array}$ & $\begin{array}{l}1-6 \\
\text { months }\end{array}$ & $7-12$ months & 12-24 months & 25 - > months \\
\hline USG+AFP & $40(48.2)$ & $11(13.3)$ & $8(9.6)$ & $24(28.9)$ \\
\hline AFP & $60(72.3)$ & $10(12.0)$ & $4(4.8)$ & 9 (10.8) \\
\hline $\begin{array}{l}\text { Advanced Fibrosis } \\
\text { (with Cirrhosis) ( } n=32) \\
\text { HCC Surveillance adherence; } n \text { (\%) }\end{array}$ & $\begin{array}{l}1-6 \\
\text { months }\end{array}$ & $\begin{array}{l}7-12 \\
\text { months }\end{array}$ & $\begin{array}{l}12-24 \\
\text { months }\end{array}$ & $25->$ months \\
\hline USG+AFP & $20(62.5)$ & $6(18.75)$ & $4(12.5)$ & $2(6.25)$ \\
\hline AFP & $24(75)$ & $6(18.75)$ & $2(6.25)$ & - \\
\hline
\end{tabular}


Based on the single evaluation of the request of AFP examination, it was requested in 60 patients every 1-6 months and in 14 patients every 7-24 months, and not requested in 9 patients (Table 3).

Moreover, the adherence rates were lower in patients treated with non-DAA antiviral regimens compared to the patients treated with DAA [for full adherence, $28.3 \% \quad(n=13)$ vs $73 \% \quad(n=27)$; $\mathrm{p}<0.001$ ] (Table 4).

\section{Effects of Patient Characteristics on Adherence to Surveillance Guidelines}

In the evaluation of patient characteristics in terms of adherence to surveillance guidelines, the rate of adherence to HCC surveillance guidelines was statistically significantly higher in the patients who are elderly ( $59 \pm 6$ vs $52 \pm 3 ; p<0.001)$, are with decompensation or a history of decompensation [86.9\% (20/23) vs $33.3 \%$ (20/60); $p<0.001$ ] and visit outpatient clinic more frequently (median $3.8 \pm 0.6$ vs $1.8 \pm 0.2 ; p<0.001$ ) compared to the patients without these characteristics.

Relationship Between the Presence of Advanced Fibrosis and Adherence to Surveillance Guidelines

Upon the achievement of SVR, the patients with cirrhosis had a higher rate of annual outpatient visits compared to the patients with non-cirrhotic advanced fibrosis (mean: 2.8 $\pm 2.2 /$ year vs $1.7 \pm 1.3$ visit/year; $p=0.014)$, two or more liver imaging $(n=22$, $68.8 \%$ vs $n=21, \% 41.2 ; p=0.026$ ) and relatively higher rate of adherence to HCC surveillance guidelines ( $n=20,62.5 \%$ vs $n=20$, $39.2 \%$; $p=0.066$ ) compared to patients with non-cirrhotic advanced fibrosis.

It was found out that one fourth of the patients with noncirrhotic advanced fibrosis did not come to their outpatient clinic visits, approximately one third of the patients did not have a liver imaging test $(31.4 \% ; 16 / 51)$ and the optimal HCC surveillance was not performed in almost two-thirds $(60.8 \% ; 31 / 51)$ of the patients (Table 3).

\section{Frequency of Development of Hepatocellular Carcinoma by Adherence to Surveillance Guidelines and Characteristics}

During the follow-up period, a total of 24 patients developed HCC $(n=14,58.3 \%$ and $n=10,41.6 \%$ respectively in the patient groups with and without adherence to the surveillance guidelines). In the group with adherence to the surveillance guidelines, the tumor size was smaller $(2.1 \pm 2.4$ vs $6.5 \pm 1.9 \mathrm{~cm} ; \mathrm{p}<0.001)$, there were more patients in Stage 0 and A according to Barcelona Clinical Liver Cancer staging ( $n=10,32.3 \%$ vs $n=1,2.9 \% ; p=0.005)$, and there were more patients meeting the Milan Liver transplant criteria ( $n=11,41.2 \%$ vs $n=2,5.9 \% ; p=0.011$ ). In the comparison in terms of AFP values, there were no values above $1000 \mathrm{ng} / \mathrm{mL}$ at the time of diagnosis in any patient in the group with adherence (Table 5).

\section{Treatments in the Patients Developing Hepatocellular Carcinoma and Follow-Up Results}

Of the patients that developed HCC, 6 were treated using locoregional treatment methods and curative resection was performed in 6 patients. Seven patients have undergone liver transplantation. Four patients died. The last patient was followed up without any treatment, as he refused all treatment options. In the group with adherence, curative resection was performed in 5 patients and 6 patients received liver transplant treatment while in the group without adherence curative resection was performed in one patient and one patient received a transplant. While one patient died in the group with adherence, 3 patients died in the group without adherence (Table 5).

\section{Discussion}

The purpose of the chronic HCV treatment is to protect the patient from the complications of chronic HCV infection by obtaining a sustained virologic response. Although SVR is achieved with treatment, patients should continue their outpatient visits for

\begin{tabular}{|l|l|l|l|l|}
\hline Table 4. Antiviral Treatment Regimes and HCC Surveillance Adherence Relationship (USG+AFP) \\
\hline HCC Surveillance adherence $\mathrm{n}(\%)$ (months) & $\mathbf{1 - 6}$ & $\mathbf{7 - 1 2}$ & $\mathbf{1 2 - 2 4}$ & $\mathbf{2 5}-\boldsymbol{>}$ \\
\hline DAAs ( $\mathrm{n}=37)$ & $\mathbf{2 7}(73.0)$ & $5(13.5)$ & $\mathbf{2}(5.4)$ & $\mathbf{3}(8.1)$ \\
\hline PEG-IF/RBV ( $\mathrm{n}=46)$ & $13(28.3)$ & $5(10.9)$ & $7(15.2)$ & $21(45.7)$ \\
\hline HCC: Hepatocellular carcinoma, DAAs: Direct acting antivirals, PEG-IF/RBV: Pegylated interferon/ribavirin & \\
\hline
\end{tabular}

Table 5. HCC development frequency and features according to adherence with surveillance

\begin{tabular}{|c|c|c|}
\hline Number of patients with HCC $(n=24)$ & $\begin{array}{l}\text { Adherence } \\
\text { with surveillance }(n=14)\end{array}$ & $\begin{array}{l}\text { Adherence } \\
\text { without surveillance }(n=10)\end{array}$ \\
\hline Tumor size $(\mathrm{cm})$; mean \pm SD & $2.1 \pm 2.4$ & $6.5 \pm 1.9$ \\
\hline 0 & 1 & 0 \\
\hline A & 9 & 1 \\
\hline $\operatorname{AFP}(\mathrm{IU} / \mathrm{mL})>1000 \mathrm{IU} / \mathrm{mL}(\mathrm{n})$ & 0 & 4 \\
\hline Liver transplantation/resection (n) & $6 / 5$ & $1 / 1$ \\
\hline Locoregional therapy $(n)$ & 3 & 3 \\
\hline
\end{tabular}


the follow-up of complications that may be developed, such as chronic liver disease or hepatocellular carcinoma. Therefore, the follow-up of the patients with advanced fibrosis with or without cirrhosis at 6-month intervals should be planned.

A total of 83 patients with SVR were included in our study. While 32 of them had cirrhosis in the pre-treatment period, 51 of them had non-cirrhotic advanced fibrosis. Based on the results of study, the patients with cirrhosis have significantly greater number of outpatient visits and imaging examinations during the follow-up period after the achievement of SVR compared to those without cirrhosis. However, although the majority of the cirrhotic patients continued their follow-up procedures after the achievement of SVR, $10 \%$ of the patients did not continue even their outpatient visits. Adherence of the non-cirrhotic $\mathrm{CHC}$ patients with advanced fibrosis to the surveillance protocols is lower compared to cirrhotic patients. When patients learn that they are cured at the end of the treatment, they think that they are not necessary to be followed up for a disease that no longer exists, and because of this thought a significant proportion of patients either discontinue the followup or skip their checks. However, some patients apply due to the development of HCC years after the achievement of SVR (12). In order to further reduce this rate, starting from the stages of diagnosis and treatment, it is of great importance to take sufficient time to the patients in outpatient visits, provide detailed information on the importance of the treatment and the follow-up after the treatment, and emphasize the potential complications over and over again.

It is a matter of concern that the rate of non-optimal surveillance for $\mathrm{HCC}$ is $22.9 \%(n=19)$ and the rate of non-surveyed patients is $28.9 \%(n=24)$. It was observed that only $61.4 \% \quad(n=51)$ of the patients were screened every 12 months and only $48.2 \%$ $(n=40)$ were screened every 6 months (USG+AFP). Although a study reporting the surveillance rates by specialty suggests that the gastroenterologists (100\%) perform more frequently HCC surveillances on patients at risk compared to nephrologists (71\%), primary care physicians (84.2\%) or internists $(88.4 \%)(p=0.016)$, the results of our study remained far from the aforementioned rate of $100 \%$ (13). This shows a poor adherence to the current guidelines and demonstrates that although HCC surveillance guidelines are regularly updated and the national and international liver diseases meetings and post-graduate training courses continue to draw attention to this issue, the concern of non-adherence to the guidelines in everyday practices still continues.

The results of our study are in line with the results of the study suggesting that HCC follow-up procedures are not sufficient in patients with $\mathrm{CHB}$ infection and sharp decreases have been observed in adherence over time during the 5-year follow-up period even in patients who were initially properly followed-up (14). The results of our study also coincide with the low adherence rates reported in other HCC surveillance studies in high-risk populations $(15,16)$

Moreover, the follow-up rates in patients treated with DAAs were significantly higher than the ones in the patients treated with non-DAA treatments. It is thought that the oral use of DAAs in a shorter period of time facilitates the treatment and the high success rate of DAA treatment reinforces the patients' trust in the treatment, and this has an effect on the adherence of the patients to the follow-up procedure after the treatment.

Development of HCC was detected in 24 (6.1\%) patients during the follow-up period in our study and 4 of them died before they even had any chance of treatment. Development of HCC is the most important complication of $\mathrm{CHC}$ in the long term and it is of vital importance. The greatest importance in determining the follow-up algorithms of the patients is attached to HCC surveillance. In a study performed in Austria in 2018, $551 \mathrm{CHC}$ patients with SVR were followed for approximately 15 months, $\mathrm{HCC}$ development was detected in $4.1 \%$ of these patients and the mortality rate was reported as 2.2\% (17).

Considering the longer follow-up period in our study, HCC development and mortality rate were lower in our study group. The fact that $71 \%$ of the patients included in that study had cirrhosis at the beginning of the study may have directly influenced the greater number of HCC development and higher mortality rates compared to our study. Moreover, although the rate of patients with genotype 3 , which are thought to have a higher risk of developing $\mathrm{HCC}$, is below $1 \%$ in our study, the said rate being $7.3 \%$ in that study seems to influence this issue.

As shown in various studies, the absence of optimal surveillance efforts affects the estimated life expectancies of the patients due to the inability to receive appropriate treatments $(18,19,20)$. Indeed, a study examining the HCC surveillance in cirrhotic patients revealed that the mean 3-year survival in this patient group showed a direct and strong correlation with the quality of the surveillance (40\% for optimal surveillance; $27 \%$ for suboptimal surveillance and $13 \%$ if no surveillance is performed, $p<0.005$ ) (8).

Our study showed that the diagnosis of HCC in adhered patients was made when the tumors were significantly smaller which allowed patients that adhere to the surveillance guidelines to receive significantly greater amount of curative treatment. Our results also confirm the results of other studies indicating that early detection of HCC increases the likelihood of receiving curative treatment $(21,22,23)$.

Since our study was performed retrospectively and was not designed to reveal whether there was a difference between the physician and the patient in terms of adherence to the surveillance guidelines, it was not reviewed whether the test and the imaging evaluations were requested by the physicians at appropriate time intervals and the patients adhered to these requests. However, it was found that the rate of performing the HCC surveillance optimally was higher in patients who had frequent outpatient visits. This may be the result of the fact that physicians are more frequently reminded of these examinations in patients with frequent visits or that patients more adhere to the physician's recommendations by remembering the importance of HCC surveillance.

Another point to be emphasized is that the patients' adherence to the physicians' recommendations may affect the rate of adherence to the HCC surveillance guidelines. Many studies address the obstacles reported by patients that decrease the adherence to the HCC surveillance guidelines. These include the length of time between the clinical visit and the performance time of radiological imaging, living far from the hospital and the limited number of clinical visits. Indeed, some patients believe that they do not need any surveillance if they are on a healthy diet, or if 
they do not have any complaints or their initial examinations gave results within the limits $(24,25)$. Yet our study was not designed to evaluate this aspect.

\section{Study Limitations}

It is reported that significant progress has been made in recent years in the treatment of $\mathrm{CHC}$ infection, which is one of the most important causes of chronic liver disease and HCC around the world and in our country, and thanks to the newly developed DAAs, a much easier and effective treatment can be administered and the global eradication of HCV may be possible. However, even if a SVR is achieved, patients with an increased risk of complications and HCC development, especially due to the presence of advanced fibrosis, should be followed and screened for HCC development at regular intervals using laboratory and imaging examinations. The gradual increase in the pool of advanced fibrosis patients that achieved a sustained virologic response due to effective treatments and the longevity of the life expectancy of this patient group lead to the rapid growth of the risky population in terms of HCC development. Our study is important since it is one of the rare studies with high patient numbers on this increasingly important subject. However, there are some limitations. First of all, its retrospective design may have caused loss of information and problems of objective evaluation. However, the use of clinical information and the detailed review of the physicians' notes allowed to evaluate the external examinations and imaging, and prevent to make any mistake in the classification of cirrhosis and HCC. There is no control group in our study and the nature of the disease does not allow any randomized, controlled, prospective study to be performed. In addition, we think that the occurrence of errors in terms of patient selection has been significantly reduced due to the fact that the study was performed in real-life conditions, although patients from a single reference center have been included.

\section{Conclusion}

HCC surveillance in patients with advanced fibrosis is not performed in accordance with the guidelines, more particularly in non-cirrhotic patients. Increased adherence to surveillance guidelines seems to facilitate the detection of HCC development at an early stage, and positively affect the survival and enable more curative treatments to be performed in the meanwhile. Since the most effective indicator of the higher adherence seems to be the increased number of visits, it is thought that the ensuring continuity in outpatient visits, maintaining more than two visits per year, and taking sufficient time at the visits to provide more information may increase the adherence of both physician and patient to the surveillance guidelines and decrease the morbidity and mortality rates.

\section{Ethics}

Ethics Committee Approval: The ethics committee approval for the study was obtained from the Local Ethics Committee of Kocaeli University (approval number: 327, date: 2019).

Informed Consent: Informed consent was obtained from all individual participants included in the study.

Peer-review: Externally peer-reviewed.

\section{Authorship Contributions}

Surgical and Medical Practices: G.Ş., S.H., Concept: G.Ş., Design: G.S.., Data Collection or Processing: G.S.., S.H., Analysis or Interpretation: G.S.., Literature Search: S.H., Writing: G.Ş.

Conflict of Interest: The authors declare no conflict of interest.

Financial Disclosure: The authors declare that this study has not received any financial support.

\section{References}

1. Wang LS, D'Souza LS, Jacobson IM. Hepatitis C-A clinical review. J Med Virol. 2016;88:1844-1855.

2. Petruzziello A, Marigliano S, Loquercio G, Cozzolino A, Cacciapuoti C. Global epidemiology of hepatitis C virus infection: An up-date of the distribution and circulation of hepatitis $\mathrm{C}$ virus genotypes. World J Gastroenterol. 2016;22:7824-7840.

3. Tozun N, Ozdogan O, Cakaloglu Y, Idilman R, Karasu Z, Akarca U, Kaymakoglu S, Ergonul O. Seroprevalence of hepatitis B and C virus infections and risk factors in Turkey: a fieldwork TURHEP study. Clin Microbiol Infect. 2015;21:1020-1026.

4. Westbrook RH, Dusheiko G. Natural history of hepatitis C. J Hepatol. 2014;61(1 Suppl):S58-68.

5. Chen SL, Morgan TR. The natural history of hepatitis C virus (HCV) infection. Int J Med Sci. 2006;3:47-52.

6. Parkin DM, Bray F, Ferlay J, Pisani P. Global cancer statistics, 2002. CA Cancer J Clin. 2005;55:74-108.

7. El-Serag HB, Rudolph KL. Hepatocellular carcinoma: epidemiology and molecular carcinogenesis. Gastroenterology. 2007;132:25572576.

8. Stravitz RT, Heuman DM, Chand N, Sterling RK, Shiffman ML, Luketic VA, Sanyal AJ, Habib A, Mihas AA, Giles HC, Maluf DG, Cotterell AH, Posner MP, Fisher RA. Surveillance for hepatocellular carcinoma in patients with cirrhosis improves outcome. Am J Med. 2008;121:119-126.

9. Schinazi R, Halfon P, Marcellin P, Asselah T. HCV direct-acting antiviral agents: the best interferon-free combinations. Liver Int. 2014;34(Suppl 1):69-78.

10. Pawlotsky JM, Negro F, Aghemo A, Berenguer $M$, Dalgard O, Dusheiko G, Marra F, Puoti M, Wedemeyer H. EASL Recommendations on Treatment of Hepatitis C 2018. J Hepatol. 2018;69:461-511.

11. Ishak K, Baptista A, Bianchi L, Callea F, De Groote J, Gudat F, Denk $H$, Desmet V, Korb G, MacSween RN, Phillips MJ, Portmann BG, Poulsen H, Scheuer PJ, Schmid M, Thaler H. Histological grading and staging of chronic hepatitis. J Hepatol. 1995;22:696-699.

12. Çelen MK, Akdemir I, Bayan K. Cure in Chronic Hepatitis C! Does it Prevent the Risk of Hepatocellular Carcinoma? Flora 2018;23:84-87.

13. Nguyen TT, Gildengorin G, Truong A, McPhee SJ. Factors influencing physicians' screening behavior for liver cancer among high-risk patients. J Gen Intern Med. 2007;22:523-526.

14. Wang C, Chen V, Vu V, Le A, Nguyen L, Zhao C, Wong CR, Nguyen $\mathrm{N}$, Li J, Zhang J, Trinh H, Nguyen MH. Poor adherence and low persistency rates for hepatocellular carcinoma surveillance in patients with chronic hepatitis B. Medicine 2016;95:e4744.

15. Palmer LB, Kappelman MD, Sandler RS, Hayashi PH. Surveillance for hepatocellular carcinoma in a Medicaid cirrhotic population. J Clin Gastroenterol. 2013;47:713-718.

16. Wong CR, Garcia RT, Trinh HN, Lam KD, Ha NB, Nguyen HA, Nguyen KK, Levitt BS, Nguyen MH. Adherence to screening for hepatocellular carcinoma among patients with cirrhosis or chronic hepatitis B in a community setting. Dig Dis Sci. 2009;54:27122721. 
17. Kozbial K, Moser S, Al-Zoairy R, Schwarzer R, Datz C, Stauber R, Laferl H, Strasser M, Beinhardt S, Stattermayer AF, Gschwantler M, Zoller H, Maieron A, Graziadei I, Trauner M, Steindl-Munda P, Hofer H, Ferenci P. Follow-up of sustained virological responders with hepatitis $\mathrm{C}$ and advanced liver disease after interferon/ ribavirin-free treatment. Liver Int. 2018;38:1028-1035.

18. Hwang JP, Hassan MM. Survival and hepatitis status among Asian Americans with hepatocellular carcinoma treated without liver transplantation. BMC Cancer. 2009;9:46.

19. Yang $B$, Zhang $B, X u Y$, Wang $W$, Shen $Y$, Zhang $A, X u Z$. Prospective study of early detection for primary liver cancer. $J$ Cancer Res Clin Oncol.1997;123:357-360.

20. Zhang $\mathrm{BH}$, Yang $\mathrm{BH}$, Tang ZY. Randomized controlled trial of screening for hepatocellular carcinoma. J Cancer Res Clin Oncol. 2004;130:417-422.

21. Mittal S, Kanwal F, Ying J, Chung R, Sada YH, Temple S, Davila JA, El-Serag HB. Effectiveness of surveillance for hepatocellular carcinoma in clinical practice: A United States cohort. J Hepatol. 2016;65:1148-1154.
22. Singal AG, El-Serag HB. Hepatocellular carcinoma from epidemiology to prevention: translating knowledge into practice. Clin Gastroenterol Hepatol. 2015;13:2140-2151.

23. Mokdad A, Browning T, Mansour JC, Zhu H, Singal AG, Yopp AC. Implementation of a voice messaging system is associated with improved time-to-treatment and overall survival in patients with hepatocellular carcinoma. J Natl Compr Canc Netw. 2016;14:3846.

24. Farvardin S, Patel J, Khambaty M, Yerokun OA, Mok H, Tiro JA; Yopp AC, Parikh ND, Marrero JA, Singal AG. Patient-reported barriers are associated with lower hepatocellular carcinoma surveillance rates in patients with cirrhosis. Hepatology. 2017;65:875-884.

25. Xu K, Watanabe-Galloway S, Rochling FA, Zhang J, Farazi PA, Peng $\mathrm{H}$, Wang $\mathrm{H}$, Luo J. Practice, Knowledge, and barriers for screening of hepatocellular carcinoma among high-risk chinese patients. Ann Glob Health. 2017;83:281-292. 